\title{
Change Management Strategies in Policies and Reforms and Administrative Functions Competence in Delta State Colleges of Education
}

\author{
Anho Joseph Efe ${ }^{1, *}$ \\ ${ }^{1}$ Department of Educational Administration and Policy Studies, Faculty of Education, Delta State University, Abraka, \\ Nigeria \\ *Correspondence: Department of Educational Administration and Policy Studies, Faculty of Education, Delta State \\ University, Abraka, Nigeria. Tel: 234-803-541-3324. E-mail: efejosiff2018@gmail.com
}

Received: June 24, 2018 Accepted: August 21, $2018 \quad$ Online Published: August 24, 2018

doi:10.5430/wje.v8n4p188

URL: https://doi.org/10.5430/wje.v8n4p188

\begin{abstract}
This research change management strategies and administrative functions competence, used the expo-facto research design of the survey method. The population of the study was made up of the 865 lecturers in the Delta State Colleges of Education in the 2015/216 academic session. The study used the stratified random sampling technique to sample 120 lecturers. The questionnaire tagged "Change Management Strategies and Administrative Function Competence” (CAMSAFC) was the main instrument used. It was validated by expert judgement and tested for reliability using the split-half method and Pearson Moment Correlation co-efficient statistics to obtain a reliability index of 0.75 , from 20 respondents of the College of Education, Ekiadalor, Edo State. The results/data from the four research questions were presented and analyzed on a table using the mean scores and standard deviation with the acceptance mean rating at 2.50 and above. The only hypothesis raised was tested using the t-test statistics for significant difference in the perception of respondents at 0.05 level of significance. The findings revealed that staff and students personnel services, curriculum and instruction, school community relations, school finance, school plant, are the main administrative functions that experience change frequently and that change management strategies commonly used includes; articulation of problems to be solved with change, collaborative approach in plan and implementing change, among others. The findings also revealed that there is no significant difference in the perception of respondents when experience is considered.
\end{abstract}

Keywords: change management, administrative competence, plans, policies, implementation

\section{Introduction}

The research uses the Kurt Lewin (1955) force field theory of change as a framework. The theory says that every behaviour is the result of maintaining equilibrium between driving force - a push in a positive direction and restraining force - a push in opposite direction resulting in performance as a result of reconciliation of the two sets of forces. Lewin work noted further that an increase in the driving forces might increase performance, but could also increase the restraining forces. Therefore, the organization institution is perceived as being in a constant state of equilibrium as a result of a balance between the two opposing sets of forces, supporting change and forces against change.

Arising from this, the Lewin's theory (1955) postulates that in order to bring about a change, the forces relating to this inter-relationship must be re-arranged or altered through some types of external intervention - this can be either by removing, weakening or strengthening one or another of the forces. Thus, an imbalance of equilibrium will result to re-adjustment that can result to change and in turn result in organizational/institutional equilibrium.

Relating Lewin (1955) field theory analysis to this research, we equate the driving forces to administrative plans, policies, reforms and decisions which influence the life of educational institutions daily; pushing the staff and students in particular directions (initiating the changes in plans, policies, reforms and decisions) and implementing and sustaining the changes lead to improvement in productivity. While resistance of pressure against change from 
stakeholders come in form of frustration, competition, demand for increase in salary/wages; change in work schedule, and competition of increase in higher prices of living. The Lewin force field theory also explain restraining forces as the act of restrain resistance or decrease in the driving forces which make it difficult to move a change forward, these include, apathy, prohibitive cost, hostility, new and advance technology, illiteracy and poor maintenance of equipment among others.

However, the theory advised that an organization have to attain what it tag "Equilibrium" which means the status quo or present level of productivity which can be disrupted or fortified by changes in the relationship between the driving and restraining forces, because for change to occur the status quo or equilibrium must be upset either by adding conditions favourable to change or by reducing resistance forces.

Lewin (1955) consequently developed a three steps strategy to manipulate the driving and restraining forces to bring about the expected change. From the works of Kaniski (2016), Agbejule (2016), Peretomode (2014), Robbins and Aluyi (2004), Stoner, Freeman and Gilbert (2004), Heller (2002), Kotter (1998), Pryor, Taneja Humphrey Anderson and Singleton (2008) who commented and analyzed the 3 steps, the following steps, processes and guidelines can be summarized as the strategies:

i. Unfreezing - Making the change so obvious and transparent that the individuals, groups or organization can easily see need for the change and accept why change must occur. Others include team building, dialogue with stakeholders, personnel development and brainstorming.

ii. Changing - Changing target group by comparing the old attitudes, values and behaviour, loyalties, trust, confidence among others with the new (proposed change) the expected change is thus made to be accepted through analysis and internalization of the effectiveness and efficiencies of the change.

iii. Refreezing - This involves transforming a new behavioural pattern into norm through enforcement and support mechanism, such as policies, rewards, and proper orientation, education and indoctrination of new personnel and managers on the new change. The change is then established as a new habit or process thereby becoming the reference point of operation in the organization/institution.

This field force theory of Lewin (1955) is thus, chosen as the background to this study as heads of tertiary institutions need novel, current and better ideas always in the day to day administration of their various institutions, since change is inevitable to be able to meet the challenges posed by the ever-changing government educational plans, policies and programmes. They also need current and relevant administrative strategies for effective administration which the three-step strategies of unfreezing, changing and refreezing provide to facilitate adaption of new attitudes, values, behaviour and the transformation of these into norms and practices. Thus, this theory is relevant, related and rational for this study as a guide for practice by the heads of tertiary educational institutions generally and Colleges of Education in particular.

\section{Administration of Change in Policies and Programmes}

Policies are sets of proposed actions and programmes purposely put together as guide to meet specific goals that are fundamental, expedient, needful for the survival and continuity of the organization/institutions. Policies intention, encompasses values, priorities, roles and guide. According to Ogbodo (2013) policies are systematized, well researched, purposive and goal-oriented course of action embarked upon by those ministering to the needs of the public. Policies may be published in Ordinance, Code, Act, Edict, Bill, Gazette, Bulletin or Newsletters. In educational institutions, policies entail all administrative rights, regulations, principles, rules, privileges, duties, actions, conducts in relation with all those that make up the institutions.

The Governance and Administration of Tertiary Education in Nigeria include management of academic activities, human and non-human resources and producing persons (student) graduates in good character and learning.

(The government/proprietors) of the educational institutions especially the Federal Government set up the National University Commission (NUC) for Universities, the National Board for Technological education for the polytechnic and the National Commission for Colleges of Education (NCCE) for Colleges of Education, these bodies co-ordinate and supervise tertiary education in Nigeria. Internally the management of the tertiary institution rest with the visitor who may be the Head of Government-President for Federal tertiary institutions and the State Governments for the State tertiary institutions. However, the day to day administration lies with the Vice- chancellors, Rectors, Provost, the Chancellor, Pro-chancellors, Registrar, Bursar and Librarian. Others may be the Deans of Faculties/Colleges or Schools and Heads of Academic and Non-academic departments. These persons have stipulated terms and period of tenure of service. 
Specifically, Colleges of Education is a form of tertiary education after secondary school, design specifically to train and prepare graduates for the teaching profession in the lower and middle classes, i.e. lower and upper basic education of 6 and junior secondary school I to 3, Colleges of Education are teacher education institutions which have as their objective the production of highly motivated, conscientious and efficient classroom teachers for the primary and post primary section.

\section{Change Management and Administration of Tertiary Education in Nigeria}

Change is something constant in life. It is felt and seen in individuals, people, ideas, beliefs, technological processes, social-political, educational-economic, institutions, organization, and in the environment. This is why, Agabi and Okorie (2002) asserted that change is naturally an enviable phenomenon which must occur. Hence, Stoner, Freeman and Gilbert, (2004) noted that every organization makes structural adjustments (change) in reaction to change in its direct and indirect forms within its environments and can be referred to as change management, which is concerned with the process of planning, organizing, leading and controlling the work of organization members and using all available organizational resources to reach stated organizational goals.

Management and administration are concepts used inter-changeably to describe the process of bringing men, materials and money together for effective, efficient and functional attainment of educational aims, goals and objectives. Management and administration involves planning, organizing, directing, supervising, co-ordinating, evaluating educational policies and programmes. However, the basic distinction in management and administration is that while educational managers refer to Ministry of Education Officials who plan, formulate policies and programmes. Educational administrators refer to those in the field or schools such as the heads and teachers/lecturers who implement the policies and programmes. In this research, management and administration will be used interchangeably to mean and refer to the same concept of planning, organizing, staffing, coordinating, directing, controlling etc.

Change management and administration involves a process of formulation and or reformulation, designing and re-designing and the implementation of educational plans, structure, policies and programmes/practices from existing plans, policies and programmes/practices aimed at improving existing ones. Such change is usually necessitated when existing educational structures, plans, policies, programme and practices become redundant, obsolete and non-functional to accomplish the earlier stated or envisage purposes, aims, goals and objectives.

Therefore, change management and administration is established or arises to meet emerging challenges. That is the reason Ogonor (2013) calls it improvement strategies which may be targeted at the policy, implementation, outcome and feedback of the total educational system or some specific aspects.

Provost of Colleges of Education as managers and administrators of human and non human are resources saddled with the responsibility to improve institutional operation, and results/outputs through meaningful productive innovations or changes.

\section{Purpose of the Study}

The purpose of this study is to examine the influence of change management strategies on administrative function competence in Delta State Colleges of Education. Specifically, the research looked at the aspects of administrative function influenced by change management strategies commonly used in administration and to establish the areas of administrative functions, that frequently experienced changes.

Finally, the study also aimed to investigated the relationship between change management strategies and administrative function competence and offered some useful suggestions.

\section{Methodology}

This research is an expost-facto design using the descriptive survey method. The target population consists of all the 865 lecturers in Delta State Colleges of Education 2015/2016 academic session. These are: College of Education, Agbor 218, College of Education, Warri 426 and College of Physical Education, Mosogar 171. The study however used the stratified random sampling technique to sample 40 lecturers from each institution. This brought the sample size to 120 . However, after distribution and collation of questionnaire, only 114 were returned thereby making the final sample size to be 114 i.e. $13 \%$ of the population. 
The instrument for data collection consists of 41 items/questionnaire, constructed with the adapted likert type rating scale of Strongly Agree $=4$ points, Agree $=3$ points, Strongly Disagree $=2$ points, Disagree 1point. The validity of the instrument was determined by two experts in the Department of Educational Administration and Policy Studies, Faculty of Education, Delta State University, Abraka.

The reliability of the instrument was obtained using split half technique with respondents from the College of Education, Ekiadolor, Edo State. The scores were analyzed using Pearson Moment correlation coefficient to get a reliability coefficient of 0.75 which suggest high reliability index.

The descriptive statistics of mean and standard deviation were used for providing answers to the research questions. A mean of 2.50 and above was used as the benchmark for acceptance. The t-test statistics was used to test the only hypothesis at 0.05 level of significance.

\section{Statement of the Problem}

Change management and administration in tertiary institution generally and Colleges of Education in particular is the process of involving the planning and implementation of changes in administrative plans, policies and programmes/activities. The institutional heads of tertiary institutions are engaged in making changes in the plans, policies and programmes of various institutions, styles of leadership, and human structure change from time to time. In the course of administration of changes, decisions have to made which may spur reaction from various stakeholders.

To render the required and expected current services of research, teaching, learning and community, service to the nation, there is need therefore to always revisit plans, policies and programmes so as to implement reform acceptable and relevant. This calls for deliberate collaboration between all stakeholders for acceptance and participation in the change.

The need for periodic review or change of academic plans, policies, programme and activities is highly necessary and desirable in view of the fact that, modern technology and innovations can make plans, policies, programmes and activities outdated and obsolete.

These include changes in administrative leadership in departments, faculties, and in the institutions leadership, such as in the appointment or removal of the vice chancellors/provost or rectors, including administrations changes in the amount of school fees to be paid, change in curricular content, change in staff or student personnel policies - salary, welfare promotion, transfer, and deployment, change in school building, facilities and equipment. These changes or reforms often lead to staff and student's agitation, protest or outright resistance. This is as the result of non-involvement of stakeholders in the change plans and implement hence this work is on change management strategies in policies and reforms and administrative function competence in Delta State Colleges of Education.

7. Research Questions: The following research questions were raised as guide;

i. What general administrative functions are influenced by change management strategies in Delta State Colleges of Education?

ii. What are the change management strategies commonly used in the administration of Delta State Colleges of Education?

iii. What are the specific areas of administrative functions that frequently experience change in Delta State Colleges of Education?

iv. What is the perception of lecturers on the relationship between change management strategies and administrative function competence in Delta State Colleges of Education?

\section{Hypotheses}

Ho1: There is no significant difference in the perception of lecturers on the relationship between change management strategies and administrative function competence when experience is considered.

\section{Presentation and Analysis of Results}

9.1 Research Question 1: What are the general administrative functions influenced by change management strategies in Delta State Colleges of Education? 
Table 1. Aspects of Administrative Functions Influenced by Change Management Strategies in deviation in Colleges of Education.

\section{Research Question 1}

\begin{tabular}{llccc}
\hline S/N & Statements/Questions & Mean & Standard Deviation & Remarks \\
\hline & & & & \\
1 & Staff/student personnel administration & 2.54 & 1.16 & Positive \\
2 & Curriculum and instruction & 2.55 & 11.7 & Positive \\
3 & School-community relations & 2.57 & 1.06 & Positive \\
4 & School finance & 2.50 & 1.15 & Positive \\
5 & School plant & 2.54 & 1.11 & Positive \\
\hline
\end{tabular}

Table I shows the mean and standard deviation of responses on the general administrative functions influenced by change management strategies in Delta State Colleges of Education. The table reveals that staff and student personnel administrative function is with a mean of 2.54, and a standard deviation of 11.6. Curriculum and instructional administration with a mean of 2.55 and standard deviation of 11.7; school community relations with mean of 2.56 and standard deviation of 1.06; school finance 2.50 and standard deviation of 1.15 and in school plant with mean of 2.54 and standard deviation of 1.11. Since the responses of all the items are above the 2.50 acceptance level, it means that all the items are general administrative functions influenced by change management strategies in Delta State Colleges of Education.

9.2 Research Question 2: What are the change management strategies commonly used in the administration of Delta State Colleges of Education?

Table 2. Mean and Standard Deviation of Change Management Strategies Commonly Used in the Administration of Delta State Colleges of Education.

\begin{tabular}{|c|c|c|c|c|}
\hline $\mathbf{S} / \mathbf{N}$ & Statements/Questions & Mean & Standard Deviation & Decision \\
\hline 6 & Articulation of problems to be solved by change & 2.52 & 1.09 & Accepted \\
\hline 7 & $\begin{array}{l}\text { Creating a structure for collective decision making } \\
\text { in planning for and implementing change }\end{array}$ & 2.57 & 1.14 & Accepted \\
\hline 8 & $\begin{array}{l}\text { Explain, train and educate personnel on the } \\
\text { purpose and benefits of anticipated change }\end{array}$ & 2.71 & 1.08 & Accepted \\
\hline 9 & $\begin{array}{l}\text { Making use of collaborative approach in planning } \\
\text { and implementing change }\end{array}$ & 2.59 & 1.01 & Accepted \\
\hline 10 & $\begin{array}{l}\text { Building in disciplinary measures for change } \\
\text { procedures/process violators }\end{array}$ & 2.54 & 1.10 & Accepted \\
\hline 11 & $\begin{array}{l}\text { Involve all stakeholders in change planning and } \\
\text { administration }\end{array}$ & 2.61 & 1.10 & Accepted \\
\hline 12 & $\begin{array}{l}\text { Establish the principle of avoiding administrative } \\
\text { conservatism }\end{array}$ & 2.54 & 1.10 & Accepted \\
\hline 13 & $\begin{array}{l}\text { Establish appraisal, assessment and general } \\
\text { evaluation of change principles, plans, procedure } \\
\text { and implementation }\end{array}$ & 2.52 & 0.09 & Accepted \\
\hline 14 & Establish change supportive mechanism & 2.84 & 0.99 & Accepted \\
\hline 15 & $\begin{array}{l}\text { Create change coordinating, supervising and } \\
\text { monitoring mechanism }\end{array}$ & 2.57 & 1.10 & Accepted \\
\hline 16 & Establish alternative change plans & 2.61 & 1.01 & Accepted \\
\hline
\end{tabular}

The table shows the mean and standard deviation of the opinions of respondents on the commonly change strategies/process used in Delta State Colleges of Education. The table reveals that all the mean of the respondents are above the acceptance level of 2.50, it therefore means that all the items/statements from 6-16 on the table are the change management strategies/processes commonly used in Delta State College of Educations.

9.3 Research Question 3: What are the specific areas of administrative functions that commonly experienced changes in Delta State Colleges of Education? 
Table 3. Respondents Mean Score and Standard Deviation on Specific Areas of Administrative Functions that Commonly Experienced Changes in Delta State Colleges of Education?

\begin{tabular}{cllll}
\hline S/N & Statements/Questions & Mean & $\begin{array}{l}\text { Standard } \\
\text { Deviation }\end{array}$ & Decision \\
\hline 17 & Change in curriculum/syllabus/course outline & 2.67 & 1.18 & Positive \\
18 & Change in Faculty/College/School and Departmental Leadership & & & \\
& Change in staff salary structure/scale & 2.57 & 1.61 & Positive \\
19 & Change in school funding policies & 2.63 & 1.04 & Positive \\
20 & Change in school fees/dues schedule & 2.54 & 1.11 & Positive \\
21 & Change in infrastructure/facilities & 2.52 & 1.14 & Positive \\
22 & Change in Admission/enrolment policies & 2.43 & 1.16 & Negative \\
23 & Change in Staff/students accommodation policies & 2.68 & 1.09 & Positive \\
24 & Change in graduation policies & & & \\
& Change in recruitment/selection policies & 2.63 & 1.04 & Positive \\
25 & Change in deployment/transfer policies & 2.56 & 1.10 & Positive \\
26 & Change in discipline/commendation policies & 2.59 & 1.06 & Positive \\
27 & Change in training/development policies & 2.51 & 1.61 & Positive \\
28 & Change in salaries/remuneration policies & 2.78 & 1.10 & Positive \\
29 & Change in retirement/pension policies & 2.56 & 1.10 & Positive \\
30 & Change in school/union leadership policies & 2.57 & 1.09 & Positive \\
31 & Change in school opening/resumption policies & 2.52 & 1.14 & Positive \\
32 & Change in school closing policies & 2.63 & 1.11 & Positive \\
33 & Change in appraisal, evaluation and assessment procedure, & 2.58 & 1.12 & Positive \\
34 & process and products policies & 2.51 & 1.61 & Positive \\
35 & Change in staff/student welfare policies & 2.54 & 1.16 & Positive \\
36 & & 2.65 & 1.11 & Positive \\
\hline
\end{tabular}

The table indicates mean and standard deviation responses on the specific areas of administrative functions that commonly experiences change. The table shows that all the items except item 22 changes in infrastructure/ facilitates are above the acceptance level. This is an indication of acceptability of items/statements as the specific administrative functions or task areas that commonly experience change in Delta State Colleges of Education.

9.4 Research Question 4: What is the perception of lecturers on the relationship between change management strategies and administrative functions competence?

Table 4. Mean Scores and Standard Deviations of Lecturers Responses on the Relationship between Change Management Strategies and Administrative Functions Competence

\begin{tabular}{lllll}
\hline S/N & $\begin{array}{l}\text { Statements/Questions } \\
\text { There is a relationship between change management } \\
\text { strategies and: }\end{array}$ & Mean & $\begin{array}{l}\text { Standard } \\
\text { Deviation }\end{array}$ & Decision \\
\hline 37 & $\begin{array}{l}\text { Effective staff and student personnel function. } \\
\text { Productive and quality curriculum and instruction } \\
38\end{array}$ & 2.51 & 1.61 & Positive \\
$\quad \begin{array}{l}\text { administrative functions. } \\
\text { Efficient and cordial school-community relations } \\
\text { administrative functions }\end{array}$ & 2.59 & 1.06 & Positive \\
$\begin{array}{l}\text { Competent and prudent school finance } \\
\text { administrative functions. } \\
\text { Available and equal well utilized school plant } \\
\text { administrative functions. }\end{array}$ & 2.56 & 1.04 & Positive \\
\hline
\end{tabular}

The table shows mean responses of lecturers on the relationship between change management strategies and administrative functions competence. Items 37 to 41 indicate that all the items have the mean score above the acceptance level of 2.50. The finding indicates that there is a relationship between change management strategies and effective and satisfactory student personnel functions; productive and quality curriculum/instruction administrative functions; effective and cordial school - community relations administrative functions; competent and prudent 
school finance administrative functions and available, adequate and well utilized school plant administrative functions. This indicates that there is a relationship between change management strategies and administrative functions competence.

10. Hypothesis I: Test of Hypothesis. There is no significant difference in the perception of lecturers on the relationship of change management strategies and administrative functions competence in Delta State Colleges of Education when experience is considered.

Table 5. T-Test Analysis of respondents' perception of the relationship between Change Management Strategies and Administrative Functions Competence in Delta State Colleges of Education When Experience is Considered

\begin{tabular}{|c|c|c|c|c|c|c|c|c|}
\hline Variables & $\mathbf{N}$ & Mean & SD & Df & $\begin{array}{l}\text { Level of } \\
\text { significance }\end{array}$ & t-cal & t-crit & Decision \\
\hline $\begin{array}{l}\text { Experienced } \\
\text { lecturers }\end{array}$ & 62 & 2.54 & 1.12 & & & & & significant \\
\hline $\begin{array}{l}\text { Less } \\
\text { experienced } \\
\text { lectures }\end{array}$ & 52 & 2.52 & 1.12 & 112 & 0.05 & 0.0096 & 1.96 & $\begin{array}{l}\text { Accept } \\
\text { null hypothesis }\end{array}$ \\
\hline
\end{tabular}

The table shows the t-test analysis of responses for significant difference on the relationship between change management strategies and administrative functions competence in Delta State Colleges of Education. The table reveals that experienced lecturers $\mathrm{N}=62$; with a mean score of 2.54 standard deviation of 1.12 and the less experienced $\mathrm{N}=52$, mean score of 2.52 and standard deviation of 1.12. The degree of difference is 112 at 0.05 level of significant difference, the t-calculated is 0.0096 and the t-critical is 1.96. It therefore indicates that there is no significant difference in the opinion/perception of lecturers on the relationship between change management strategies and administrative function competence in Delta State Colleges of Education when experience is considered.

\section{Discussion of Findings}

Table 1 revealed that staff/student personnel administration, curriculum and instruction, school-community relations, school finances and school plant are general administrative functions influenced by change management strategies.

These functions are also referred to as administrative task areas. This finding supports the identified broad categorization of administrative task areas of the school administrator by Gorton (1983, pp. 47-49). The finding is also in line with the works of Great Schools, (2014) which says that Great Principals (school administrators) lead in the task of teaching and learning; (curriculum $\mathrm{x}$ instruction) concern with the school's physical environment and other facilities, (school plant), develop and retain excellent teachers (personnel function) and build a strong school community.

The findings from research question 2 which asked of the change management strategies commonly used in Delta State Colleges of Education reveal all the items to be the strategies commonly used in administration. These are articulation of problems, creating a structure for collective decision making, explaining/training stakeholders on the purpose and benefit of change, collaborative approach in planning and implementing change, building in disciplinary measures for violators of change procedure/process, establishing appraisal, assessment and general evaluation of change principles, avoiding administrative conservatism, establishing change supportive mechanism, creating change coordinating, supervising, and monitoring mechanism and establishing alternative change plans. These findings support the advise of Hislton (2000:7) that co-operative team work and partnering strategy is good for managing changes in educational policies, this is an approach to change implementation.

Change management strategies is the act of creating, fashioning or making plans toward the attainment of a purpose, this refer to the administrative technique, skill or behaviour which are used in maneuvering against obstacles in the course of planning and implementing changes to achieve educational goals and objectives. This finding supports the works of Freeman and Gilbert (2004) that every organization (tertiary institutions included) makes structural adjustments (changes) in reaction to change in its direct or indirect actions within its environment. So also the works of Nwaka (2010) who listed good knowledge of interpersonal relations and integrating subordinates in decision making among other as good skills for a competent change administration. Similarly, Lai (2013) outline some change management strategies as ways of overcoming the challenges in implementing change policies and 
programmes to inc1ude: sensitizing stakeholders, provision of change infrastructure, proper maintenance and training among others. Muraina (2014) in writing on management skills needed by school heads for administrative effectiveness listed among others good decision making skills, discipline, feedback and organization skills.

The findings from research question three reveals the specific areas of administrative function that commonly experienced change. These include changes in policies in curricula syllabus or course outline, changes in leadership, staff salary structure/scale, school funding, school fees schedule, infrastructure/facilities, policies on admission, enrolment, accommodation, student graduation, recruitment/selection, deployment, transfer, discipline, recommendation, training/develop, salaries/remuneration, retirement/pension, union leadership school opening/resumption, closing, staff appraisal assessment, procedure, process and products and change in staff/student welfare policies.

The finding shows that the all areas of the administrative functions experience changes. changes in administration is constant. This agrees with Robbins and Aluyi (2004) who asserted that change is therefore constant and inherent in life, including schools. Teaching and learning demand good services delivery and practices in the system which should be based on sound policies reviewed periodically for acceptance, for continuity after due consultation. This calls for good administrative change management skills in the departments of leadership. The finding supports the views of Nnabuo (2001) who explains educational management as involving activities that are designed to discern and influence the development of goals and policies as basic to teaching and learning, facilitate the planning and operation of appropriate programmes and procure management personnel and material to implement teaching and learning.

Research question four reveals that there is no significant difference in the perception of lectures on the relationship between change management strategies administrative function competence. The findings of Ogonor (2013) is in consonance with this finding which she calls improvement strategies which are targeted at the policy implementation, outcome and feedback sequences of the total educational system or some pacific aspects. These specific aspects Mullins (2012) referred to as the eight spheres of university administration which is also applicable to universities, polytechnics, colleges of education, secondary and primary school administration. These are space, finances, students' academic programmes, committee system, personnel, welfare, reward system and physical facilities. The work of Nwakpa (2015) is also related who found that students and staff personnel management is a serious function of the school administrator as it is an indispensable care and functions task of the school administrator. Next to staff and student personnel is curriculum and instruction. This is in line with Anho (2006) who identified curriculum and instructional task as one of the most important functions of the university management as schools are set up mainly to achieve set up curriculum and instructional objectives. The school head helps relate the desired curriculum to available time, physical facilities and personnel. They also help in the supervision of instruction.

The finding also supports Peretomode (2014) who highlighted the importance of community-school relationship as the function of school head; to include among others to develop and administering policies, and procedures for parents and community participation in school matters and help to develop and implement plans for the improvement of community life.

Similarly, the views of Pryor, Taneja, Huinpreys, Anderson and Singleton (2008) who noted that change is constant and leaders should anticipate change and react rapidly and responsibly to be successful. Peretomode (2014) emphasis the relationship between change management and administration competence when he advised that school administrators should adopt to change so as not to be overwhelmed by it.

Agambi and Okorie (2002) asserted that change is naturally an evitable phenomenon which must occur in every organization (institution) Stoner, Freeman and Gilbert (2004) calls it structural adjustment which requires good management for the attainment of organizational goal in every organization.

\section{Conclusion}

Change is a constant in life, felt and seen in individuals, people, ideas, beliefs, technological processes, social-political, educational-economic institutions and organization change is therefore on evitable phenomenon which must occur prompting people, institutions and organization to make structural adjustments in reaction to the change. This adjustment is what is referred to as change management strategies. Since every change efforts or strategies requires good management which is concerned with the process of planning, organizing, leading and controlling the work of the institution or organization to proper for attempt of the educational goals, policies and programme. This work concludes that change management strategies positively relates with administrative 
competence.

\section{Recommendations}

- $\quad$ Tertiary institution leaders and other school heads should understand the change management strategies and adhere to them strictly when planning and implementing changes in their various administrative functions in their institutions.

- $\quad$ Institutional plans, policies and programmes should be reviewed periodically for acceptance and for continuity.

- Institutional/school heads should create a structure to involve all stakeholders in collaborative decision making, and to avoid the practice of administrative conservatism, but to establish change supportive mechanism.

- $\quad$ Articulation of problems to be solved by change, explain, train and educate personnel on the purpose and benefits of changes, building in disciplinary measures for changes to procedures violators, make use of collaborative approach in planning and implementing changes, create change co-ordinating, supervising and monitoring mechanism.

\section{References}

Agabi, O.G., \& Okorie, N.C. (Eds.) (2002). Introduction to management of change in Education: A book of readings. Port-Harcourt: Pam Unique Publishing Coy.

Agbejule, P.E. (2016). Principles assessment of implementation of educational reforms in Delta and Rivers State. Unpublished Ph.D. Thesis in Educational Administration, Delta State University, Abraka.

Anho, J.E. (2006). Identification and Analysis of Problems n Administration of Students Personnel Support Services in Nigerian Universities. Unpublished Ph.D. Thesis Educational Administration, Delsu, Abraka.

Change Management Coach (2016). Force Field Analysis Kurt Lewin: change-management-coach.com 2015, Retrieved $11^{\text {th }}$ Feb., 2016.

Dean (2014). Quality of a good principal. Teaching and learning Edubabbling for the Masses. Retrieved from www.edubabbling.com/qualities-of-a-good-principal

Gorton, R.A. (1983). School Administration and Supervision: Important Issues, Concepts and Case Studies. Dubugwe, Lowa: Wnfc Brown Company Publishers.

Great School (2004). What makes a great principal? Retrieved from www.greatschools.org/improvement/quality-teaching

Kotter J.P. (1998). The leadership factor. New York: The Free Press.

Kotter, J.P. (1996). The Leadership “Kill Complacency”. Fortune (August), 5, 168-170.

Lai, E. (2013). What do School Principals do to overcome the Challenges of Implementing a New Senior Secondary Curriculum in Hong Kong? Cypriot Journal of Education Sciences, 8(4), 370-380.

Lewin, K. (1955). Field Force Analysis, In Kaminski, J. (2016). Lewin’s Change Theory. Canadian Journal of Nursing Informatics (2006-2016), 6(1). Retrieved March, 2016 from http://cjni.net/journal= 1210

Meyer, J.P., \& Allen, N.J. (1984). Testing the side bet theory of organizational commitment; some methodological considerations. Journal of Applied Psychology, 69, 372-378. https://doi.org/10.1037/0021-9010.69.3.372

Meyer, J.P., \& Allen, N.J. (1997). Commitment in the Work Place: Theory, Research and Applications. Thousand Oaks: Sage.

Mulkeen, A., Chapman D.W., DeJaeghere J.G., \& Leu, F. (2007). Recruiting, Retaining and Retraining Secondary school Teachers and Principals in Sub-Saharan Africa, In Arikewuyo M.O. (2009), professional training of secondary school principals in Nigeria, a neglected area in the educational system. Florida Journal of Educational Administration and Policy, 2(3).

Mullins, L.J. (2002). Management and organizational behavior. Essx: Pearson Education Ltd. Edinburgh Gate.

Muraina, M.B. (2014). Managerial Skills and Administrative Effectiveness in Secondary Schools in Oyo State Nigeria. Global Journal of Management of Business Research, an Admin. \& Mgt. V., 14(3).

Nakpodia, E.D. (2013). Human Resources Management. Atitoni Publication Ltd., Warri. 
Nnabuo, P.O.M. (2001). Essential of Educational Management. Lagos: Africa Heritage Publications.

Nwaka, N.G. (2010). Secondary School Administration in Anambra State Today: Challenges and the Way Forward. African Research Review, An International Multi-Disciplinary Journal, Ethiopia, 4(2). https://doi.org/10.4314/afrrev.v4i2.58351

Ogbodo, C.M. (2013). Knowledge Production in Higher Education: Policies and Practices in Nigeria. African Journal of Higher Education Studies and Development (AJHESD) CHES UNIPORT Centre for Higher Education Studied. https://doi.org/10.5539/ies.v6n12p9

Ogonor B.O. (2013). School Improvement Strategies for Educational Goal Altainment in Above the Ivory Tower. In P.O. Ikoya (Ed.), A book of honour of Professor Eric A Arubayi, pp 95-105 University Printing Press, Delta State University, Abraka.

Ogunu, M. (2000). Introduction to Educational Management. Benin City: Mogogun Publishers.

Peretomode, V. F. (2014). Theories of Management Implications for Educational Administration. University Printing Press, Delta State University, Abraka, Nigeria.

Peretomode, V.F. (2012). Leadership: Principles and Theoretical Perspective. Benin City: Justice-Jeco Publishers Ltd.

Pryor, M.G., Taneja Humphreys, J., Anderson, D., \& Singleton. (2008). Challenges facing among management theories and research. Delhi Business Review, 9(1).

Robbins, P., \& Aluyi, H. (2004). The New Principals’ field book, Strategies for Success. Alexandra: Association for Supervision and Curriculum Development.

Stoner, James A.F. (2004). Management, Engle Wood Clif. New Jersey; Prentice Hill Inc. New Edition. 